\title{
Characterization of novel genic SSR markers in Linum usitatissimum (L.) and their transferability across eleven Linum species
}

\author{
Braulio J. Soto-Cerda ${ }^{1 \#} \square \cdot$ Hector Urbina Saavedra $^{1} \cdot$ Cristell Navarro Navarro $^{1} \cdot$ Paula Mora Ortega $^{1}$ \\ 1Centro de Genómica Nutricional Agro-Acuícola, Unidad de Genómica y Bioinformática, INIA-Carillanca, Temuco, Chile \\ $\triangle$ Corresponding author: braulio.soto@cgna.cl \\ Present address: Cereal Research Center, Agriculture and Agri-Food Canada, Winnipeg, Canada \\ Received September 1, 2010 / Accepted January 26, 2011 \\ Published online: March 15, 2011 \\ (C) 2011 by Pontificia Universidad Católica de Valparaíso, Chile
}

\begin{abstract}
Little is known about the evolutionary relationships among Linum species, basically because of the lack of transferable molecular markers. Currently, expressed sequence tags available in public databases provide an opportunity for the rapid and inexpensive development of simple sequence repeat (SSR) markers in wild flax species. In this regard, fifty expressed sequence tag-derived microsatellite markers (EST-SSRs) were evaluated for polymorphism and transferability in 50 Linum usitatissimum cultivars/accessions and 11 Linum species. Among them 23 EST-SSRs were polymorphic in L. usitatissimum, while 2-4 alleles were detected (average 2.26 per locus). The polymorphism information content value ranged from 0.08 to 0.55 (average 0.38 ). Forty one genic markers $(95.3 \%)$ produced strong amplicons in at least two of the 11 Linum species. The percentage of cross amplification ranged from $34.1 \%$ to $92.7 \%$ in $L$. tauricum and L. bienne, respectively. Moreover, the rate of transferability was associated positively with the botanical section. Our results suggest that the high degree of EST-SSRs transferability to Linum species can be a useful enhancement of the current database of SSR markers for future genetic and evolutionary studies.
\end{abstract}

Keywords: EST-SSRs, expressed sequence tag, flaxseed, polymorphic loci, wild relatives

\section{INTRODUCTION}

Linum is the largest genus of the Linaceae family comprising nearly 200 species (Heywood, 1993) divided into six botanical sections: Linum, Linastrum, Cathartolinum, Dasylinum, Syllinum and Cliococca (Winkler, 1931). This genus has more than 100 species that exhibit a wide range of diversity in morphological characters and life forms (Gill, 1987). Their uses can vary from industrial to ethnobotanic applications. For instance, Linum usitatissimum is the most important species of the genus due to its industrial applications in fiber, oil and functional foods production. Furthermore, $L$. bienne the wild progenitor of cultivated flax is a potential donor of new alleles for $L$. usitatissimum genetic improvement. With regard to the evolutionary relationships among species of the genus Linum efforts have been carried out based on morphological characters, chromosome numbers and karyological studies (Gill, 1987; Muravenko et al. 2010).

Nowadays, molecular characterization of cultivated flax as well as studies of potential evolutionary pathways of wild flax species have been assessed using Amplified Fragments Length Polymorphism (AFLP) (Everaert et al. 2001), Random Amplified Polymorphic DNA (RAPD) (Fu, 2006) and Inter Simple Sequence Repeat (ISSR) markers (Wiesnerova and Wiesner, 2004; Uysal et al. 2010). However, this goal has been partially achieved using the current molecular tools. Comparison across taxa is still lacking since many marker systems are more or less species specific. When they are amplified across different species not necessarily are compared the same genomic regions which can conduct to erroneous conclusions (Pashley et al. 2006). Although, Genomic Simple Sequence Repeats (G-SSRs) have been developed in cultivated flax (Roose-Amsaleg et al. 2006; Deng et al. 2010; SotoCerda et al. 2010) their transferability to related species is generally low because they commonly occur in noncoding regions of the genome which are not highly conserved (Kim et al. 2008). Moreover, 
homoplasy is another limitation of G-SSRs in evolutionary studies where identical band sizes may not be identical by descent (Thiel et al. 2003). Thus, one of the major challenges in the molecular analyses across the Linum species is the generation of informative and transferable molecular markers. On the contrary, Expressed Sequence Tag-derived microsatellite (EST-SSRs) or genic SSRs are popular because they are derived from transcription products and conserved coding sequences; as a consequence they exhibit a high rate of transferability to other species (Eujayl et al. 2004; Varshney et al. 2005; Ellis and Burke, 2007; Hisano et al. 2007; Iñiguez-Luy et al. 2008). In addition, they are costeffective, co-dominant and useful for studying functional diversity, comparative mapping and interspecific linkage map construction (Varshney et al. 2005). Recently, Cloutier et al. (2009) reported the only EST-SSRs collection developed in cultivated flax which were included in the first linkage map in L. usitatissimum (Cloutier et al. 2010). Subsequently, Fu and Peterson (2010) utilized part of these genic SSRs to characterize their transferability to Linum species. It is noteworthy that this EST-SSRs collection provides new molecular tools for Linum studies. Nonetheless, they are still limited for performing a wide genome comparison among the species of the genus Linum. Therefore, in order to achieve a comprehensive understanding of the genetic diversity and genome evolution of the genus Linum as well as to use wild relatives in linseed breeding, more informative genic SSRs should be developed.

The objective of this study was to evaluate the informative value and transferability of 50 new genic SSR primers in $50 \mathrm{~L}$. usitatissium cultivars/accessions and 11 Linum species, so that they can be use for future molecular characterizations in Linum species.

\section{MATERIALS AND METHODS}

\section{Plant material and DNA extraction}

A total of 50 L. usitatissimum cultivars/accessions and 11 species of genus Linum, divided in 4 botanical sections were selected for screening polymorphism and transferability of the EST-SSR primers, respectively. Thirty four cultivars/accessions of cultivated flax and the eleven Linum species were provided by Dr. Axel Diederichsen, Plant Gene Resources of Canada. Sixteen Chilean linseed cultivars/accessions were provided by the Germplasm Bank of the Agricultural Research Institute of Chile INIA, Carillanca (Table 1). DNA was extracted from fresh, young leaf tissue using the CTAB method (Doyle and Doyle, 1987). In cultivated flax, DNA was isolated from a single plant per cultivar/accession. On the other hand, in Linum species 5 plants were bulked. The quality and final concentration was estimated by spectrometry using a MBA 2000 Perkin Elmer spectrometer.

\section{Sequence database and EST-SSRs detection}

A total of 7960 Expressed Sequence Tag (EST) sequences of L. usitatissium available by May 1, 2009 were retrieved from $\mathrm{NCBI}$ database. The identification of sequences containing repeats, redundancy and primers design was performed in accordance with Soto-Cerda et al. (2010). The parameters for designing the primers were: length $18-27$ bp with 20 being optimum, Polymerase Chain Reaction (PCR) product size of $100-300 \mathrm{bp}$, optimum annealing temperature of $60^{\circ} \mathrm{C}$ and $\mathrm{GC}$ content of $20-80 \%$. A subset of 50 primer pairs was custom synthesized by Sigma-Aldrich (St. Louis, MO), giving priority to trinucleotide motifs.

\section{PCR amplification and electrophoresis}

All PCR amplifications were carried out following the PCR conditions developed by Soto-Cerda et al. (2010). PCR products were separated by $6 \% 8 \mathrm{M}$ urea polyacrylamide gel electrophoresis and visualized by the silver staining method (Bassam et al. 1991). Fragment sizes for each locus were determined using $50 \mathrm{bp}$ DNA ladder (Promega, USA). The quality of the SSR loci was expressed as the Polymorphism Information Content (PIC) as described by Botstein et al. (1980). In addition, transferability was considered successful when the amplicons were in the size range predicted for $L$. usitatissimum. 
Table 1. Germplasm collection used in the evaluation of polymorphism and transferability of genic SSRs in $L$. usitatissimum and species of the genus Linum. CN: Canadian number. IC: Chilean number.

\begin{tabular}{|c|c|c|c|c|c|}
\hline $\begin{array}{l}\text { Accession } \\
\text { number }\end{array}$ & Name & Origin & $\begin{array}{l}\text { Accession } \\
\text { number }\end{array}$ & Name & Origin \\
\hline CN 101540 & $\begin{array}{l}\text { Sel Clli- } \\
2156(C 4)\end{array}$ & Canada & CN 100763 & Clli-3229 & USA \\
\hline CN 101453 & Sel Clli-647(C4) & Canada & CN 100769 & Clli-3246 & USA \\
\hline CN 101515 & $\begin{array}{l}\text { Sel Clli- } \\
1987(C 4)\end{array}$ & Canada & CN 72585 & 84495 & Australia \\
\hline CN 101519 & $\begin{array}{l}\text { Sel Clli- } \\
1997(C 4)\end{array}$ & Canada & CN 98042 & $10484 / 46$ & Argentina \\
\hline CN 101466 & $\begin{array}{l}\text { Sel Clli- } \\
1472(C 4)\end{array}$ & Canada & IC-1 & Ten-C1 & Chile \\
\hline CN 101593 & $\begin{array}{l}\text { Sel Clli- } \\
2697(C 4)\end{array}$ & Canada & IC-2 & $\mathrm{Gr}-\mathrm{C} 2$ & Chile \\
\hline CN 18975 & AC Carnduff & Canada & IC-3 & Vilcun & Chile \\
\hline CN 18974 & CDC Bethume & Canada & IC-4 & Ro-C4 & Chile \\
\hline CN 18979 & Flanders & Canada & IC-5 & $\mathrm{Pa}-\mathrm{C} 5$ & Chile \\
\hline CN 72584 & Macbeth & Canada & IC-6 & N8-C66 & Chile \\
\hline CN 72582 & Lightning & Canada & IC-7 & Sau-C77 & Chile \\
\hline CN 33385 & Linott & Canada & IC-8 & San-C88 & Chile \\
\hline CN 44316 & Vimy & Canada & IC-9 & $\mathrm{KZ}-41$ & Chile \\
\hline CN 18973 & AC Watson & Canada & IC-10 & FC10 & France \\
\hline CN 19004 & AC Emerson & Canada & IC-11 & Ar-C111 & Chile \\
\hline CN 96846 & Clli-643 & Russia & IC-12 & Ent-C112 & Chile \\
\hline CN 97520 & Clli-576 & Russia & IC-13 & Bad-C13 & Chile \\
\hline CN 101241 & AP6 & Russia & IC-14 & $\mathrm{CC} 14$ & Canada \\
\hline CN 101247 & VNIIL-5628 & Russia & IC-15 & HLS-3 & Chile \\
\hline CN 30860 & Kirovogradskij71 & Ukraine & IC-16 & HLS-4 & Chile \\
\hline CN 33396 & Vera & Czechoslovakia & CN 107257 & $\begin{array}{l}\text { L. bienne } \\
(n=15, \text { Linum })\end{array}$ & Egypt \\
\hline CN 98753 & Clli-2702 & France & CN 107273 & $\begin{array}{l}\text { L. pallescens } \\
(n=9,15, \text { Linum })\end{array}$ & Unknown \\
\hline CN 97459 & Roman Winter & Netherlands & CN 107286 & $\begin{array}{l}\text { L. altaicum } \\
(n=9, \text { Linum })\end{array}$ & Unknown \\
\hline CN 97096 & Clli-1995 & Pakistan & CN 19026 & $\begin{array}{l}\text { L. grandiflorum } \\
(n=8,9, \text { Linum })\end{array}$ & Algeria \\
\hline CN 98239 & Clli-1829 & Pakistan & CN 107264 & $\begin{array}{l}\text { L. narbonense } \\
(n=14, \text { Linum })\end{array}$ & Unknown \\
\hline CN 100629 & Murgzani & Pakistan & CN 19185 & $\begin{array}{l}\text { L. lewisii } \\
(n=9, \text { Linum })\end{array}$ & Unknown \\
\hline CN 96920 & Clli-1416 & Turkey & CN 107271 & $\begin{array}{l}\text { L. hirsutum } \\
(n=8,9, \\
\text { Dasylinum })\end{array}$ & Romania \\
\hline CN 97153 & Clli-2052 & Turkey & CN 107269 & $\begin{array}{l}\text { L. tenuifolium } \\
(n=9, \\
\text { Linastrum })\end{array}$ & Unknown \\
\hline CN 98192 & Clli-1685 & Morocco & CN 107277 & $\begin{array}{l}\text { L. strictum } \\
(n=9, \\
\text { Linastrum })\end{array}$ & Unknown \\
\hline \multirow[t]{2}{*}{ CN 19002} & Omega & USA & CN 107275 & $\begin{array}{l}\text { L. tauricum } \\
(n=? \text { Syllinum })\end{array}$ & Unknown \\
\hline & & & CN 19180 & $\begin{array}{l}\text { L. flavum } \\
(n=14,15, \\
\text { Syllinum })\end{array}$ & Mediterranean \\
\hline
\end{tabular}

MJM (Meerut jute microsatellites). 


\section{RESULTS AND DISCUSSION}

\section{Distribution of EST-SSRs and polymorphism}

Of the 7960 EST sequences examined, 494 genic SSRs were found in 436 non-redundant sequences $(5.4 \%)$ which account for an average density of 1 SSR every $9.51 \mathrm{~Kb}$. In general, it is estimated that 2$5 \%$ of all plant-derived ESTs harbor SSRs (Varshney et al. 2005; Pashley et al. 2006), matching our results in the expected range. Among them the most abundant motifs were trinucleotides $(57.1 \%)$ followed by tetra- $(17.2 \%)$, penta- $(11.7 \%)$, hexa- $(7.1 \%)$, mono- $(5.9 \%)$ and di- $(1.0 \%)$. This result is in accordance with other studies in Arabidopsis (Morgante et al. 2002), Festuca arundinacea (Saha et al. 2004), durum wheat (Wang et al. 2007) and cultivated flax (Cloutier et al. 2009) where trimeric repeats were more abundant. Unlike other plant species such as Lactuca sativa (Simko, 2009) and $L$. usitatissimum (Cloutier et al. 2009) dinucleotide motifs were underrepresented. One possible explanation for such difference is that the majority of the ESTs analyzed in our study derived from a stem phloem fiber BAC library which did not cover the whole genome of $L$. usitatissimum. For instance, Cloutier et al. (2009) used 10 cDNA libraries to generate cultivated flax ESTs representing tissues from bolls, stem, globular embryos, heart stage embryos, seed coat at torpedo stage; thereby it is guaranteed homogenous genome coverage. Furthermore, tri- and hexanucleotide SSRs seem to be under positive selection since they do not cause frameshift mutation in ESTs coding region owing to they are multiples of three, the number of nucleotides in codons. This is not the case of dinucleotide motifs whose number could be under negative selection (Varshney et al. 2005).

Forty three primer pairs amplified expected size alleles (86\%) while $23(53.5 \%)$ were polymorphic in $L$. usitatissimum. This is higher than EST-SSRs reported in wheat $(25 \%)$, sorghum $(45 \%)$ and cultivated flax (40.7\%) (Eujayl et al. 2002; Cloutier et al. 2009, Yonemaru et al. 2009), but lower than another study in L. usitatissimum (62.2\%) (Roose-Amsaleg et al. 2006). Differences in polymorphism might be attributable to the genomic origin of the SSRs developed by Roose-Amsaleg et al. (2006) considered more polymorphic than EST-SSRs. Nonetheless, they are not directly comparable since their evolution is explained by different factors in transcribed and non-transcribed sequences. These new genic SSR primers were identified with the prefix LM "Linum Microsatellite" (Table 2). No multi loci EST-SSR primers were detected, in total 23 reproducible loci (Figure 1a). The total number of alleles was 52, ranging from 2 to 4, with an average of 2.26 alleles per locus. Commonly, EST-SSRs are reported to show lower allele variation than G-SSRs (Simko, 2009). Indeed, Roose-Amsaleg et al. (2006) and Deng et al. (2010) reported in G-SSRs an average of 3.32 and 3.45 alleles per locus, respectively. On the other hand, Cloutier et al. (2009) reported similar results between the two studies based on ESTSSRs (2.3 alleles per locus) which would confirm the assumption exposed above. In this study we prioritized trinucleotide EST-primers since in G-SSRs have been demonstrated that they are more polymorphic (Song et al. 2002). However, our results showed low polymorphism in EST-SSRs carrying trimeric repeats. Similarly, the low variability of trimeric EST-SSR loci was reported in Oryza sativa (Cho et al. 2000) and Pinus taeda (Liewlaksaneeyanawin et al. 2004). On the contrary, dimeric ESTSSRs with high numbers of repeats seem to have high polymorphism, as do genomic SSRs. The relationship between polymorphism and the number of repeats has been reported for EST-SSRs in barley (Thiel et al. 2003) and G-SSRs in cultivated flax (Soto-Cerda et al. 2010). PIC values ranged from 0.08 to 0.55 with an average of 0.38 . These results are quite similar to those reported by Cloutier et al. (2009) (average 0.35). Nevertheless, when trimeric PIC values were compared between the two studies our results were higher $(0.38$ versus 0.33$)$. On the contrary, when the average PIC value of the EST-SSRs was compared with G-SSRs, this tend to be lower, i.e., L. usitatissimum 0.56 (Deng et al. 2010) Musa acuminata 0.48 (Wang et al. 2010), common bean 0.45 (Hanai et al. 2007) and Brassica oleracea 0.48 (Iñiguez-Luy et al. 2008). Nonetheless, $69.56 \%$ of genic SSRs showed PIC values up the average, suggesting that informative SSRs can be obtained from L. usitatissimum ESTs.

\section{EST-SSRs transferability across the Linum species}

Forty one EST-primer pairs (95.3\%) produced strong amplicons in at least two of the eleven species of the genus $L$ inum. The percentage of transferability ranged from $34.1 \%$ to $92.7 \%$ in $L$. tauricum and $L$. bienne and $L$. pallescens, respectively (Table 2 ). Among botanical sections the average transferability was $72.4 \%$ Linum, $58.5 \%$ Dasylinum, $58.5 \%$ Linastrum and $52.4 \%$ Syllinum. Interestingly, in the section Linum the lowest rate of cross-amplification was observed in $L$. narbonense $(41.5 \%)$. This species markedly differs from the other species of the section by the number and size of chromosomes, their C-banding pattern and location of ribosomal genes (Muravenko et al. 2010). In addition, by morphology and size, $L$. narbonense chromosomes are more similar to chromosomes of $L$. 
hirsutum which agree with botanists that $L$. narbonense systematic position needs to be refined (Muravenko et al. 2010) as suggested by the low level of EST-SSRs transferred to this species. Our results indicate a positive correlation between the rate of transferability and the botanical section. For instance, Roose-Amsaleg et al. (2006) and $\mathrm{Fu}$ and Peterson (2010) reported $85.7 \%$ and $97 \%$ of transferable G-SSR and EST-SSR loci in L. bienne ( $n=15$, Linum), respectively. This indicates that this species shares a high sequence similarity and genome background with cultivated flax. Indeed $L$. bienne is known as the wild progenitor of cultivated flax from previous morphological, cytological and molecular characterizations (Samadi et al. 2007; Diederichsen and Fu, 2008; Uysal et al. 2010), and it is considered the primary gene pool for crossing with cultivated flax (Diederichsen and Fu, 2008; Cloutier et al. 2009). Both species produce interfertile $F_{1}$ progenies (Gill and Yermanos, 1967), share the same chromosomes number, and have similar chromosomes morphology and C-banding pattern (Muravenko et al. 2003). With regard to L. pallescens ( $n=9,15$, Linum) there also exist reports of hybridization with $L$. usitatisiimum with normal meiosis and fertile $F_{1}$ progenies (Gill and Yermanos, 1967). When we observed $L$. grandiflorum ( $n=9$, Linum) this disclosed $78 \%$ of cross-amplification. Interestingly, this species has been used for the induction of dihaploid embryos in L. usitatissimum improvement (Diederichsen and Richards, 2003). Hybridization between inter botanical sections have also been reported; i.e. L. usitatissimum $(n=15$, Linum $) \times$ L. hirsutum $(n=9$, Dasyllinum) and L. usitatissimum ( $n=15$, Linum) $\times$ L. strictum ( $n=9$, Linastrum) (Jhala et al. 2008). These species disclosed $58.5 \%$ and $78 \%$ of transferability, respectively. Although plant morphology and karyotype are important factors in taxonomy classification, the primary criterion is the ability to cross hybridize and produce fertile offsprings (Diederichsen and Richards, 2003). It stated that the level of transferability success reduces as the evolutionary distance and sexual compatibility between the source and the target species increases (Liewlaksaneeyanawin et al. 2004; Simko, 2009). This statement supports the number of transferable EST-SSRs to these five species of the genus Linum which might indicate that similar functional sequences are shared with $L$. usitatissimum to induce chromosome pairing in artificial hybridizations. Examples from tomato (Tanksley and McCouch, 1997), lettuce (Jeuken and Lindhout, 2004) and rice (Nguyen et al. 2003) represent successful gene introgressions from wild relatives which is a real option for linseed breeding. The remarkable level of transferability supports previous findings in other plant species (Saha et al. 2004; Varshney et al. 2005; Pashley et al. 2006; Fu and Peterson, 2010). These results confirm the usefulness of EST-SSRs since they are derived from transcribed and conserved regions of the DNA, allowing cross-species transferability (Eujayl et al. 2004; Sim et al. 2009). In addition, the four botanical sections belong to the genus Linum; for which higher rates of transferability of EST-SSR loci is expected within genus (Eujayl et al. 2004; Pashley et al. 2006) as confirmed by $\approx 65 \%$ of average cross amplification in our study. Twenty six primers $(63.41 \%)$ showed polymorphism inter-species, disclosing 85 total putative bands ranging from 2-5 with an average of 2.07 per locus (Figure $1 \mathrm{~b}$ ). On the other hand, $34.1 \%$ of them disclosed multi allele/loci compared to $L$. usitatisimum amplicons which might entail intra-species variation as a consequence of bulked samples. By the contrary, other possible reason could be the high rate of conservation of EST sequences, suggesting amplifications from either orthologous or paralogous copies (Saha et al. 2004; Sim et al. 2009), particularly in polyploidy species such as $L$. narbonense (Muravenko et al. 2010). Similarly, Yu et al. (2004) reported that $39 \%$ of EST-SSRs detected multiple loci in wheat (hexaploide). As a result, to elucidate this question sequence analysis should be carried out in the future. In fact, sequencing PCR amplicons of EST-SSRs have shown high similarities, especially within genus (Zhang et al. 2005; Pashley et al. 2006). Our results suggest that EST-SSRs might help to elucidate the evolutionary relationships of Linum species, providing genetic information from cultivated flax to its wild relatives and vise versa (Sim et al. 2009). Among polymorphic loci in L. usitatissimum, 69.6\% showed polymorphism across Linum species. Furthermore, $55.5 \%$ of the monomorphic loci in L. usitatissimum were informative in the other Linum species, indicating that monomorphic EST-SSRs developed for one species might display allele variation in other related taxa (Cloutier et al. 2009).

This study confirms that by data mining was possible to develop inexpensive, informative and transferable EST-SSRs in L. usitatissimum and related species. The high rate of transferability validates their potential application for fingerprinting, functional diversity, comparative mapping and Marker Assisted Selection (MAS) with emphasis on those interfertile species such as $L$. bienne and $L$. pallescens. From our point of view is an urgent need that more EST-SSRs being developed since the current number is still lacking for whole genome analysis in the genus Linum. 
Table 2. Characterization of genic SSR markers in L. usitatissimum and their transferability to 11 Linum species.

\begin{tabular}{|c|c|c|c|c|c|c|c|c|c|c|c|c|c|c|c|c|c|c|c|}
\hline \multirow[t]{2}{*}{$\begin{array}{c}\text { Bank } \\
\text { accession } \\
n^{\circ} \\
\end{array}$} & \multirow[t]{2}{*}{$\begin{array}{l}\text { Locus } \\
\text { name }\end{array}$} & \multirow[t]{2}{*}{ Primer sequence $\left(5^{\prime} \rightarrow 3^{\prime}\right)$} & \multirow[t]{2}{*}{$\begin{array}{l}\text { Repeat } \\
\text { motif }\end{array}$} & \multirow[t]{2}{*}{$\begin{array}{l}\text { Expected } \\
\text { size bp }\end{array}$} & \multirow[t]{2}{*}{$\begin{array}{c}\mathbf{N}^{\circ} \\
\text { alleles }\end{array}$} & \multirow[t]{2}{*}{ PIC } & \multicolumn{13}{|c|}{ Transferability to Linum species } \\
\hline & & & & & & & L. b. & L. p. & L.a. & L. $g$. & L. $n$. & L.I. & L. $h$. & L.t. & L.s. & L.ta. & L. f. & $\begin{array}{c}\mathbf{N}^{\circ} \\
\text { putative } \\
\text { alleles }\end{array}$ & $\begin{array}{l}\text { Multi } \\
\text { loci* }\end{array}$ \\
\hline EX720235.1 & LM-42 & $\begin{array}{l}\text { GAATGAGGAACACCGGAAAG } \\
\text { ATCCAAGTGAACTTGCCTCC }\end{array}$ & $(\mathrm{CCA})_{5}$ & 163 & 2 & 0.28 & + & + & + & + & + & + & - & + & + & - & + & 4 & - \\
\hline EX720209.1 & LM-43 & $\begin{array}{l}\text { GCTGACGAAGGAGAAGGAAG } \\
\text { CATACGCAAAAGGAGAAGGC }\end{array}$ & $(G G A)_{5}$ & 172 & 3 & 0.55 & + & + & + & + & + & - & + & + & + & - & + & 4 & - \\
\hline EX720185.1 & LM-44 & $\begin{array}{l}\text { AACCAACAACTACGCCTTGG } \\
\text { GGGAGACTTTTTGAGTCGAGAG }\end{array}$ & $(\mathrm{ATG})_{6}$ & 171 & 1 & M & + & + & + & - & + & + & + & + & + & + & + & 2 & - \\
\hline EX720157.1 & LM-45 & $\begin{array}{l}\text { GTGATGATGATGGTGGCG } \\
\text { GCTCTTCACACTCCCCAGAG }\end{array}$ & $(\mathrm{TCT})_{5}$ & 209 & 3 & 0.54 & + & + & + & - & + & + & - & - & + & + & + & 3 & - \\
\hline EX720130.1 & LM-46 & $\begin{array}{l}\text { CGGATCCTTATAGCCTGCTG } \\
\text { TCCTGGTGCAACCATTACAG }\end{array}$ & $(\mathrm{AAG})_{6}$ & 162 & 3 & 0.43 & + & + & - & + & - & - & - & - & - & - & - & 1 & - \\
\hline EX720114.1 & LM-47 & $\begin{array}{l}\text { CСGTTCACTTTCTCСTCTGC } \\
\text { GGAGACCGAAATTCCAACAC }\end{array}$ & $(\mathrm{AAG})_{5}$ & 161 & 1 & $M$ & + & + & - & - & - & + & - & + & - & - & + & 3 & - \\
\hline EX720099.1 & LM-48 & $\begin{array}{l}\text { GGAGGAATAGCGAGCACAAG } \\
\text { TGGTGGTCTTCTGTCCACAC }\end{array}$ & $(\mathrm{GCA})_{5}$ & 162 & 2 & 0.47 & + & + & + & + & - & - & + & - & - & + & + & 2 & - \\
\hline EX720068.1 & LM-49 & $\begin{array}{l}\text { GATCCCCAATCCGATCTTTC } \\
\text { GCTTATCGGAGTACCTCGGC }\end{array}$ & $(A G G)_{5}$ & 208 & 2 & 0.40 & + & + & + & + & + & + & + & + & - & + & + & 2 & - \\
\hline EX720059.1 & LM-50 & $\begin{array}{l}\text { CATCTTTGCAGTGAAGGTGG } \\
\text { GAAAATTGCAGGCTCTCTCC }\end{array}$ & $(\mathrm{GAT})_{5}$ & 188 & 2 & 0.29 & - & + & - & + & - & - & + & - & - & - & - & 1 & - \\
\hline EX720044.1 & LM-51 & $\begin{array}{l}\text { CGTCTGTTTCACTCCTCAGC } \\
\text { GAGGCACCCATGGTGAAC }\end{array}$ & $(\mathrm{TCT})_{6}$ & 198 & 2 & 0.49 & + & + & - & + & - & + & - & - & + & - & + & 2 & - \\
\hline EX720477.1 & LM-53 & $\begin{array}{l}\text { AGAGGAAAATGGAAGAGGCG } \\
\text { CTGAGAAGAGTTGCCACCAG }\end{array}$ & $(A C G)_{5}$ & 150 & 2 & 0.39 & + & + & - & + & - & + & + & + & + & - & + & 2 & - \\
\hline EX720432.1 & LM-53 & $\begin{array}{l}\text { GCATGAGCTCAACAGTCCAG } \\
\text { CGCAGAACAACCTTTGGG }\end{array}$ & $(\mathrm{CAG})_{5}$ & 203 & 1 & $M$ & + & - & - & - & + & - & - & - & - & - & - & 1 & - \\
\hline EX720405.1 & LM-54 & $\begin{array}{l}\text { GGAACCGCAGCTGGACTTAG } \\
\text { AAGTAGGCAAGGGTAATGCG }\end{array}$ & $(A G A)_{6}$ & 189 & 2 & 0.50 & + & + & - & + & - & + & + & - & + & + & + & 2 & + \\
\hline EX720361.1 & LM-55 & $\begin{array}{l}\text { TAGACGAGACCCAGCAGAGC } \\
\text { ATGATGAGTCCGGTGAGGAG }\end{array}$ & $(A G A)_{5}$ & 154 & 4 & 0.39 & + & + & + & + & + & + & + & + & + & + & + & 2 & + \\
\hline
\end{tabular}




\begin{tabular}{|c|c|c|c|c|c|c|c|c|c|c|c|c|c|c|c|c|c|c|c|}
\hline EH792583.1 & LM-56 & $\begin{array}{l}\text { AGCTTGTGATGCTGATGGTG } \\
\text { CGAGGGATACTCTAGAGCGG }\end{array}$ & $(T A A)_{6}$ & 161 & 1 & $M$ & $\mathrm{n} / \mathrm{e}$ & $\mathrm{n} / \mathrm{e}$ & $\mathrm{n} / \mathrm{e}$ & $n / e$ & $\mathrm{n} / \mathrm{e}$ & $\mathrm{n} / \mathrm{e}$ & $\mathrm{n} / \mathrm{e}$ & $\mathrm{n} / \mathrm{e}$ & $\mathrm{n} / \mathrm{e}$ & $\mathrm{n} / \mathrm{e}$ & $\mathrm{n} / \mathrm{e}$ & $\mathrm{n} / \mathrm{e}$ & $\mathrm{n} / \mathrm{e}$ \\
\hline EH792520.1 & LM-58 & $\begin{array}{l}\text { TCTCCTGCAGCCTCCACTAC } \\
\text { TCCTATCCAACAATCCGTCG }\end{array}$ & $(\mathrm{GCC})_{5}$ & 196 & 1 & $M$ & + & + & - & - & - & + & + & - & + & - & + & 1 & - \\
\hline $\mathrm{EH} 792442.1$ & LM-59 & $\begin{array}{l}\text { ATTGGATGCTGGATGGAGAC } \\
\text { ATGATCAGTAAAGGCGGCAG }\end{array}$ & $(G C A)_{6}$ & 193 & 1 & $M$ & + & + & + & + & + & + & + & - & + & + & + & 2 & + \\
\hline $\mathrm{EH} 792413.1$ & LM-60 & $\begin{array}{l}\text { AAGACGCTGCTGAATCATTG } \\
\text { TATCACGCAACTCCAGCTTC }\end{array}$ & $(\mathrm{GAA})_{5}$ & 162 & 2 & 0.49 & + & + & + & + & + & + & + & - & + & - & + & 1 & - \\
\hline $\mathrm{EH} 792342.1$ & LM-61 & $\begin{array}{l}\text { TGGGTGAAGAAAAGAAAGAGG } \\
\text { GCAACCTTCCTAGCACAAGC }\end{array}$ & $(\mathrm{AAG})_{5}$ & 178 & 1 & $M$ & - & - & - & + & - & - & - & - & - & - & - & 1 & - \\
\hline EH792318.1 & LM-62 & $\begin{array}{l}\text { AACCAGCAGCTTCCAAAGAC } \\
\text { GAGGGTTAGGAAAGCTACAATC }\end{array}$ & $(A G G)_{5}$ & 155 & 2 & 0.39 & + & + & + & + & + & + & + & + & + & + & + & 3 & - \\
\hline EH792278.1 & LM-63 & $\begin{array}{l}\text { TATTTCATGCACCGCAAAAC } \\
\text { GTCATTTCCCTTCCTCCTCC }\end{array}$ & $(G A G)_{6}$ & 180 & 1 & M & + & + & + & - & + & + & + & + & + & - & + & 2 & + \\
\hline EH792257.1 & LM-65 & $\begin{array}{l}\text { TTCACAAGGCCTAACCCATC } \\
\text { AGCACACTTCTCCTTCAGGG }\end{array}$ & $(\mathrm{ATC})_{5}$ & 166 & 1 & $M$ & + & + & + & + & - & + & + & - & + & - & + & 2 & + \\
\hline $\mathrm{EH} 792225.1$ & LM-66 & $\begin{array}{l}\text { TTATTATTAATTCAACCACAACGC } \\
\text { CGATGAAGCTTGTGATGCTG }\end{array}$ & $(\mathrm{TAT})_{7}$ & 152 & 1 & $M$ & + & + & - & - & - & - & - & - & + & - & - & 1 & - \\
\hline $\mathrm{EH} 792154.1$ & LM-67 & $\begin{array}{l}\text { ACTGCGAAATCGAGATCAGG } \\
\text { GAGGAGGCAAAGCCAAAGTC }\end{array}$ & $(\mathrm{CCA})_{6}$ & 177 & 1 & $M$ & + & + & - & + & - & + & + & - & + & - & - & 2 & + \\
\hline EH792070.1 & LM-68 & $\begin{array}{l}\text { GAATTCCCGGGATATCGAAC } \\
\text { AGCATGGTGGTGCTGGTG }\end{array}$ & $(\mathrm{CAT})_{4}(\mathrm{CAT})_{5}$ & 168 & 1 & M & $\mathrm{n} / \mathrm{e}$ & $\mathrm{n} / \mathrm{e}$ & $\mathrm{n} / \mathrm{e}$ & $n / e$ & $\mathrm{n} / \mathrm{e}$ & $\mathrm{n} / \mathrm{e}$ & $\mathrm{n} / \mathrm{e}$ & $\mathrm{n} / \mathrm{e}$ & $\mathrm{n} / \mathrm{e}$ & $\mathrm{n} / \mathrm{e}$ & $\mathrm{n} / \mathrm{e}$ & $\mathrm{n} / \mathrm{e}$ & $\mathrm{n} / \mathrm{e}$ \\
\hline EH792050.1 & LM-69 & $\begin{array}{l}\text { ATACTTGGCTAGTGGTGGCG } \\
\text { TCTCCAGAACCCTGAACACC }\end{array}$ & $(\mathrm{TGA})_{5}$ & 155 & 2 & 0.44 & + & + & - & + & - & - & - & + & + & - & - & 1 & - \\
\hline EH791974.1 & LM-70 & $\begin{array}{l}\text { AAAGGCAGGCACATCAAGAG } \\
\text { TGGGAAGAGGAAGAGGAGTTG }\end{array}$ & $(\mathrm{GAA})_{6}$ & 205 & 3 & 0.41 & + & + & + & + & - & + & + & + & + & + & + & 3 & + \\
\hline EH791902.1 & LM-71 & $\begin{array}{l}\text { ATGACAATGCTCCTCCATCC } \\
\text { GGCGGTACTTGTGAGCAGG }\end{array}$ & $(\mathrm{CAT})_{5}$ & 168 & 1 & $M$ & + & + & - & + & - & - & - & - & - & - & - & 1 & - \\
\hline EH791837.1 & LM-72 & $\begin{array}{l}\text { СТTCСССТTСТССТССТСАG } \\
\text { АСTTGTСАСССАССТСАТGC }\end{array}$ & $(G G C)_{6}$ & 168 & 2 & 0.30 & + & + & - & + & - & + & - & - & + & - & - & 1 & - \\
\hline EH791736.1 & LM-73 & $\begin{array}{l}\text { ATACCCTACTGTTGCTGGGC } \\
\text { TTGACTGTCATGGCTAATGGAG }\end{array}$ & $(\mathrm{GAT})_{5}$ & 184 & 2 & 0.39 & + & + & + & + & - & + & - & - & + & - & + & 1 & - \\
\hline
\end{tabular}




\begin{tabular}{|c|c|c|c|c|c|c|c|c|c|c|c|c|c|c|c|c|c|c|c|}
\hline EH791609.1 & LM-74 & $\begin{array}{l}\text { CTTACCGTCCCCAGCCATAC } \\
\text { CGGTGAATACGGAGAGAAGG }\end{array}$ & $(\mathrm{TCC})_{6}$ & 193 & 1 & $M$ & + & + & - & + & - & + & + & + & + & + & + & 1 & - \\
\hline $\mathrm{EH} 791602.1$ & LM-75 & $\begin{array}{l}\text { CCGCCGGAAAAAGAATTTAC } \\
\text { TGAGGAGGTAATGGGTGACG }\end{array}$ & $(\mathrm{CAG})_{5}$ & 161 & 1 & $M$ & + & + & + & + & + & + & + & + & + & + & + & 1 & - \\
\hline EH791368.1 & LM-76 & $\begin{array}{l}\text { GATATCGTCGACCCACGC } \\
\text { GCACTCGAAGCACACTTCTC }\end{array}$ & $(\mathrm{ATC})_{5}$ & 150 & 2 & 0.40 & + & + & + & - & + & + & + & - & + & - & + & 2 & - \\
\hline $\mathrm{EH} 791352.1$ & LM-77 & $\begin{array}{l}\text { CTTTTGAAGCTATGGCGGAG } \\
\text { CTGCAGACCTCCGACTCTTC }\end{array}$ & $(\mathrm{TTC})_{8}$ & 165 & 1 & M & + & - & - & - & - & - & - & - & - & - & + & 3 & - \\
\hline EH791256.1 & LM-79 & $\begin{array}{l}\text { GCAACAGCAGCAGTAAGCAG } \\
\text { TAATTCGCCACCACGCTTAG }\end{array}$ & $(\mathrm{CAT})_{5}$ & 173 & 2 & 0.18 & + & + & + & + & + & + & - & + & + & + & + & 3 & + \\
\hline EH791220.1 & LM-80 & $\begin{array}{l}\text { CCACAACCAAATGGGAAATC } \\
\text { CCCATTTGACAGCAAAACTC }\end{array}$ & $(\text { ATC })_{6}$ & 156 & 2 & 0.42 & + & + & + & + & + & + & + & + & + & + & + & 3 & + \\
\hline EH791187.1 & LM-81 & $\begin{array}{l}\text { TCAACACCTTCAACACCACC } \\
\text { GTCCTTTGGATGGAAGGAGG }\end{array}$ & $\begin{array}{c}(\mathrm{CAG})_{5}(\mathrm{GGA}) \\
5\end{array}$ & 154 & 1 & $M$ & + & + & - & + & - & + & - & - & - & - & - & 1 & - \\
\hline CA483361.1 & LM-84 & $\begin{array}{l}\text { CTTCCCAAAGAAGACCCTCC } \\
\text { CTTTTTCAGCTGAGCTTGGG }\end{array}$ & $(\mathrm{GAA})_{7}$ & 174 & 1 & $M$ & - & + & - & + & - & + & - & - & - & - & - & 2 & - \\
\hline CA483453.1 & LM-85 & $\begin{array}{l}\text { CACCCCTGCTGGAAACAG } \\
\text { CGATAGCCAATGGATTCGTC }\end{array}$ & $(\mathrm{ACA})_{5}(\mathrm{ATA})_{6}$ & 185 & 2 & 0.15 & + & + & + & + & - & + & + & - & + & - & + & 1 & - \\
\hline CV478207.1 & LM-86 & $\begin{array}{l}\text { ACCTTTCCCAACCATAACCC } \\
\text { AATTCGGGTCAGAAGCAATG }\end{array}$ & $(\text { ATA })_{6}$ & 185 & 2 & 0.08 & + & + & + & + & + & + & - & - & + & - & - & 5 & + \\
\hline CV478210.1 & LM-87 & $\begin{array}{l}\text { GACTATGGCCTTTCAGCACC } \\
\text { AGCTCTCAGAGTTCATCAAACG }\end{array}$ & $(\mathrm{CTT})_{10}$ & 169 & 2 & 0.22 & + & + & + & + & - & + & + & - & + & - & + & 3 & + \\
\hline CV478252.1 & LM-88 & $\begin{array}{l}\text { CCTGATCTCCATAACTTCCCC } \\
\text { GAAAATTGGTGTCGGCGG }\end{array}$ & $(\mathrm{CAA})_{6}$ & 151 & 1 & $M$ & + & + & - & + & - & + & + & - & - & - & + & 3 & + \\
\hline \multirow[t]{2}{*}{ CV478306.1 } & LM-89 & $\begin{array}{l}\text { GGGAGAGAAGGGATTGGAAG } \\
\text { TCCTGCATACACACCTTCAAC }\end{array}$ & $(T A G)_{6}$ & 156 & 1 & $M$ & + & + & + & + & + & + & + & + & + & + & + & 4 & + \\
\hline & & & & & Tranfer & ity (\%) & 92.8 & 92.8 & 53.7 & 78 & 41.5 & 75.6 & 58.5 & 39 & 78 & 34.1 & 70.7 & & \\
\hline
\end{tabular}

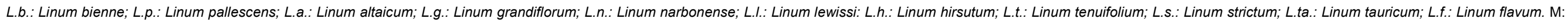
Monomorphic markers in L. usitatissimum. n/e: not expected size allele in Linum species. ${ }^{*}$ EST-SSR markers which amplify potential multi allele/loci in Linum species. Annealing temperature was set at $60^{\circ} \mathrm{C}$. 


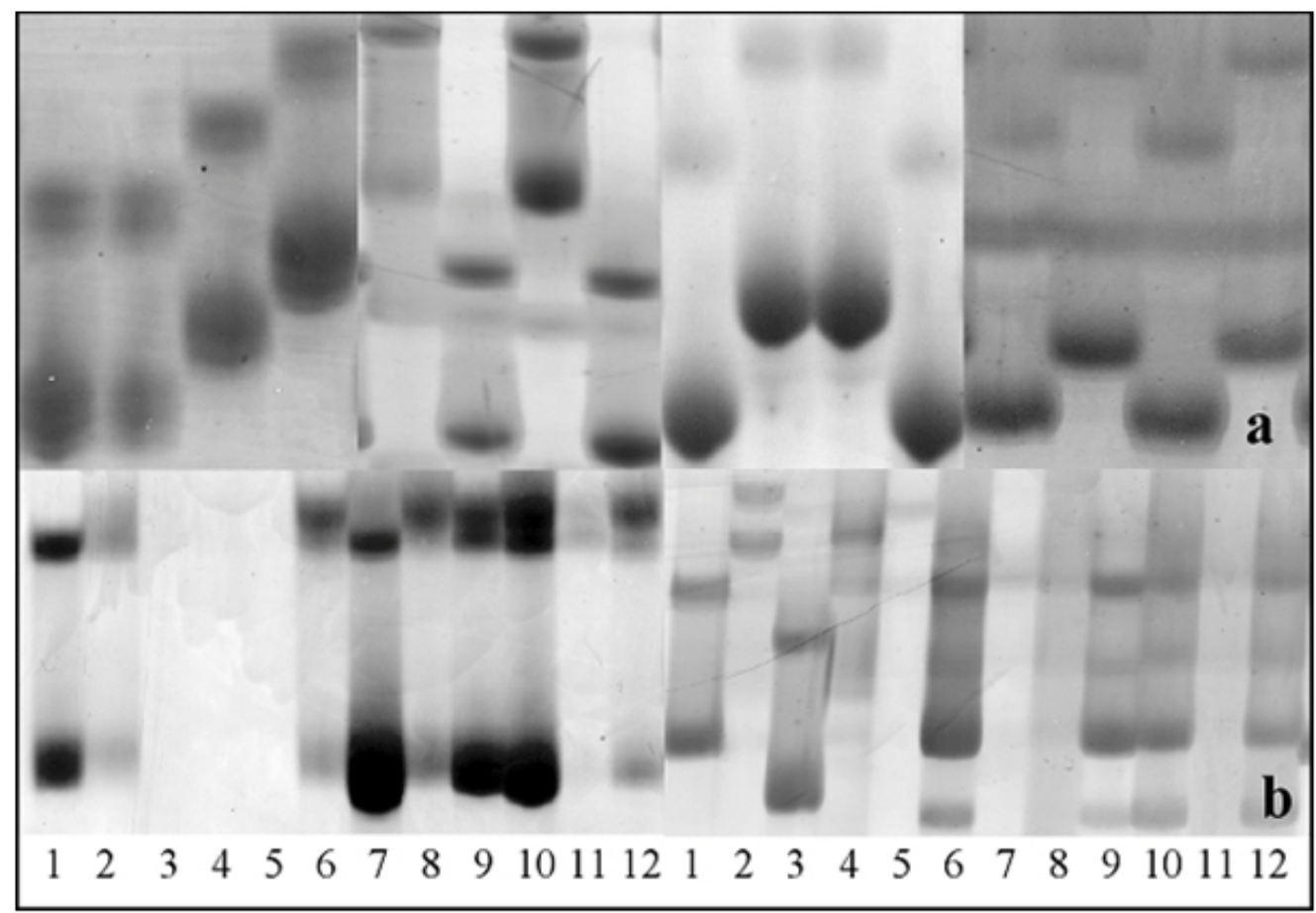

Fig. 1 Amplification patterns in EST-SSR markers. (a) Polymorphic loci in L. usitatissimum (from the left) LM-46, LM-55, LM-62 and LM-80. (b) Polymorphic and transferable loci LM-54 (left) and LM-43 (right) in 11 species of the genus Linum. 1 L. usitatissimum (control Canadian cultivar AC Watson) 2. L. bienne 3. L. pallescens 4. $L$ altaicum 5. L. grandiflorum 6. L. narbonense 7. L lewissi 8. L hirsutum 9. L. tenuifolium 10. L strictum 11. L. tauricum 12. $L$ flavum.

\section{ACKNOWLEDGMENTS}

The authors are grateful to Dr. Axel Diederichsen and Dr. Gastón Muñoz for supplying the germplasm utilized in this study.

Financial support: This work was supported by CGNA, Centro de Genómica Nutricional Agro-Acuícola, AraucaníaChile.

\section{REFERENCES}

BASSAM, B.J.; CAETANO-ANOLLES, G. and GRESSHOFF, P.M. (1991). Fast and sensitive silver staining of DNA in polyacrylamide gels. Analytical Biochemistry, vol. 196, no. 1, p. 80-83. [CrossRef]

BOTSTEIN, D.; WHITE, R.L.; SKOLNICK, M. and DAVIS, R.W. (1980). Construction of a genetic linkage map in man using restriction fragment length polymorphisms. American Journal of Human Genetics, vol. 32, no. 3, p. 314-331.

CHO, Y.G.; ISHII, T; TEMNYKH, S. CHEN, X; LIPOVICH, L. McCOUCH, S.R.; PARK, W.D; AYRES, N. and CARTINHOUR, S. (2000). Diversity of microsatellites derived from genomic libraries and GenBank sequences in rice (Oryza sativa L.). TAG Theoretical and Applied Genetics, vol. 100, no. 5, p. 713-722. [CrossRef]

CLOUTIER, S.; NIU, Z.; DATLA, R. and DUGUID, S. (2009). Development and analysis of EST-SSRs for flax (Linum usitatissimum L.). TAG Theoretical and Applied Genetics, vol. 119, no. 1, p. 53-63. [CrossRef]

CLOUTIER, S.; RAGUPATHY, R.; NIU, Z. and DUGUID, S. (2010). SSR-based linkage map of flax (Linum usitatissimum L.) and mapping of QTLs underlying fatty acid composition traits. Molecular Breeding, Online first. [CrossRef]

DENG, X.; LONG, S.; HE, D.; LI, X.; WANG, Y.; LIU, J. and CHEN, H. (2010). Development and characterization of polymorphic microsatellite markers in Linum usitatissimum. Journal of Plant Research, vol. 123, no. 1, p. 119123. [CrossRef] 
DIEDERICHSEN, A. and RICHARDS, K. (2003). Cultivated flax and the genus Linum L. Taxonomy and germplasm conservation. In: MUIR, A.D. and WESTCOTT, N.D. eds. Flax: The genus Linum. 11 New Fetter Lane, London, 2003, p. 22-54.

DIEDERICHSEN, A. and FU, Y.B. (2008). Flax genetic diversity as the raw material for future success. In: International conference on flax and other bast plants, July 21-23, 2008, Saskatchewan, Canada. p. 270-280.

DOYLE, J.J. and DOYLE, J.L. (1987). A rapid DNA isolation procedure for small quantities of fresh leaf tissue. Photochemistry Bulletin, vol. 19, no. 3, p. 11-15.

ELLIS, J.R. and BURKE, J.M. (2007). EST-SSRs as a resource for population genetic analysis. Heredity, vol. 99, no. 2, p. 125-132. [CrossRef]

EUJAYL, I.; SORRELLS, M.E.; BAUM, M.; WOLTERS, P. and POWELL, W. (2002). Isolation of EST-derived microsatellite markers for genotyping the A and B genomes of wheat. TAG Theoretical and Applied Genetics, vol. 104, no. 2-3, p. 399-407. [CrossRef]

EUJAYL, I.; SLEDGE, M.K.; WANG, L.; MAY, G.D.; CHEKHOVSKIY, K.; ZWONITZER, J.C. and MIAN, M.A.R. (2004). Medicago truncatula EST-SSRs reveal cross-species genetic markers for Medicago spp. TAG Theoretical and Applied Genetics, vol. 108, no. 3, p. 414-422. [CrossRef]

EVERAERT, I.; DE RIEK, J.; DE LOOSE, M.; VAN WAES, J. and VAN BOCKSTAELE, E. (2001). Most similar variety grouping for distinctness evaluation of flax and linseed (Linum usitatissimum L.) varieties by means of AFLP and morphological data. Plant Varieties and Seeds, vol. 14, no. 2, p. 69-87.

FU, Y.B. (2006). Redundancy and distinctness in flax germplasm as revealed by RAPD dissimilarity. Plant Genetic Resources, vol. 4, no. 2, p. 117-124. [CrossRef]

FU, Y.B. and PETERSON, G.W. (2010). Characterization of expressed sequence tag-derived simple sequence repeat markers for 17 Linum species. Botany, vol. 88, no. 5, p. 537-543. [CrossRef]

GILL, K.S. and YERMANOS, D.M. (1967). Cytogenetic studies on the genus Linum I. hybrids among taxa with 15 as the haploid chromosome number1. Crop Science, vol. 7, no. 6, p. 623-627. [CrossRef]

GILL, K.S. (1987). Linseed. Publications and Information Division. Indian Council of Agricultural Research, New Delhi, India. 386 p. ISBN 0-271-74-0.

HANAI, L.R.; DE CAMPOS, T.; CAMARAGO, L.E.A.; BENCHIMOL, L.L.; DE SOUZA, A.P.; MELOTTO, M.; CARBONELL, S.A.M.; CHIORATTO, A.F.; CONSOLI, L.; FORMIGHIERI, E.F., SIQUEIRA, M.V.B.M.; TSAI, S.M. and VIEIRA, M.L.C. (2007). Development, characterization, and comparative analysis of polymorphism at common bean SSR loci isolated from genic and genomic sources. Genome, vol. 50, no. 3, p. 266-277. [CrossRef]

HEYWOOD, V.H. (1993). Flowering plants of the world. Oxford, Oxford University Press, 336 p. ISBN 0-19-5210379.

HISANO, H.; SATO, S.; ISOBE, S.; SASAMOTO, S.; WADA, T.; MATSUNO, A.; FUJISHIRO, T.; YAMADA, M.; NAKAYAMA, S.; NAKAMURA, Y.; WATANABE, S.; HARADA, K. and TABATA, S. (2007). Characterization of the soybean genome using EST-derived microsatellite markers. DNA Research, vol. 14, no. 6, p. 271-281. [CrossRef]

IÑIGUEZ-LUY, F.L.; VOORT, A.V. and OSBORN, T.C. (2008). Development of a set of public SSR markers derived from genomic sequence of a rapid cycling Brassica oleracea L. genotype. TAG Theoretical and Applied Genetics, vol. 117, no. 6, p. 977-985. [CrossRef]

JHALA, A.J.; HALL, L.M. and HALL, J.C. (2008). Potential hybridization of flax with weedy and wild relatives: An avenue for movement of engineered genes? Crop Science, vol. 48, no. 3, p. 825-840. [CrossRef]

JEUKEN, M.J.W. and LINDHOUT, P. (2004). The development of lettuce backcross inbred lines (BILs) for exploitation of the Lactuca saligna (wild lettuce) germplasm. TAG Theoretical and Applied Genetics, vol. 109, no. 2, p. 394-401. [CrossRef]

KIM, K.S.; RATCLIFFE, S.T.; FRENCH, B.W.; LIU, L. and SAPPINGTON, T.W. (2008). Utility of EST-derived SSRs as population genetics markers in a beetle. Journal of Heredity, vol. 99, no. 2, p. 112-124. [CrossRef]

LIEWLAKSANEEYANAWIN, C.; RITLAND, C.E.; EL-KASSABY, A.Y. and RITLAND, K. (2004). Single-copy, species-transferable microsatellite markers developed from loblolly pine ESTs. TAG Theoretical and Applied Genetics, vol. 109, no. 2, p. 361-369. [CrossRef]

MORGANTE, M.; HANAFEY, M. and POWELL, W. (2002). Microsatellites are preferentially associated with nonrepetitive DNA in plant genomes. Nature Genetics, vol. 30, no. 2, p. 194-200. [CrossRef]

MURAVENKO, O.V.; LEMESH, V.A.; SAMATADZE, T.E.; AMOSOVA, A.V.; GRUSHETSKAYA, Z.E.; POPOV, K.V.; SEMENOVA, O.L.U.; KHOTUYLEYA, L.V. and ZELENIN, A.V. (2003). Genome comparisons with chromosomal and molecular markers for three closely related flax species and their hybrids. Genetika, vol. 39, no. 4, p. 414-422. [CrossRef]

MURAVENKO, O.V.; BOLSHEVA, N.L.; YURKEVICH, O.Y.; NOSOVA, I.V.; RACHINSKAYA, O.A.; SAMATADZE, T.E. and ZELENIN, A.V. (2010). Karyogenomics of species of the genus Linum L. Russian Journal of Genetics, vol. 46, no. 10, p. 1182-1185. [CrossRef]

NGUYEN, B.; BRAR, D.; BUI, B.; NGUYEN, T.; PHAM, L.N. and NGUYEN, H.T. (2003). Identification and mapping of the QTL for aluminum tolerance introgressed from the new source, ORYZA RUFIPOGON Griff., into indica rice (Oryza sativa L.). TAG Theoretical and Applied Genetics, vol. 106, no. 4, p. 583-593. [CrossRef]

PASHLEY, C.H.; ELLIS, J.R.; MCCAULEY, D.E. and BURKE, J.M. (2006). EST databases as a source for molecular markers: Lessons from Helianthus. Journal of Heredity, vol. 97, no. 4, p. 381-388. [CrossRef]

ROOSE-AMSALEG, C.; CARIOU-PHAM, E.; VAUTRIN, D.; TAVERNIER, R. and SOLIGNAC, M. (2006). Polymorphic microsatellite loci in Linum usitatissimum. Molecular Ecology Notes, vol. 6, no. 3, p. 796-799. [CrossRef]

SAHA, M.C.; MIAN, M.A.R.; EUJAYL, I.; ZWONITZER, J.C.; WANG, L. and MAY, G.D. (2004). Tall fescue ESTSSR markers with transferability across several grass species. TAG Theoretical and Applied Genetics, vol. 109, no. 4, p. 783-791. [CrossRef] 
SAMADI, A.; MAHMODZADEH, A.; GORTTAPEH, A.H. and TORKAMANI, M.R. (2007). Cytogenetic studies in four species of flax (Linum spp.). Journal of Applied Sciences, vol. 7, no. 19, p. 2833-2839. [CrossRef]

SIM, S.C.; YU, J.K.; JO, Y.K.; SORRELLS, M.E. and JUNG, G. (2009). Transferability of cereal EST-SSR markers to ryegrass. Genome, vol. 52, no. 5, p. 431-437. [CrossRef]

SIMKO, I. (2009). Development of EST-SSR markers for the study of population structure in lettuce (Lactuca sativa L.). Journal of Heredity, vol. 100, no. 2, p. 256-262. [CrossRef]

SONG, Q.J.; FICKUS, E.W. and CREGAN, P.B. (2002). Characterization of trinucleotide SSR motifs in wheat. TAG Theoretical and Applied Genetics, vol. 104, no 2-3, p. 286-293. [CrossRef]

SOTO-CERDA, B.J.; CARRASCO, R.A.; ARAVENA, G.A.; URBINA, H.A. and NAVARRO, C.S. (2010). Identifying novel polymorphic microsatellites from cultivated flax (Linum usitatissimum L.) following data mining. Plant Molecular Biology Reporter, Online first. [CrossRef]

TANKSLEY, S. and MCCOUCH, S. (1997). Seed banks and molecular maps: Unlocking genetic potential from the wild. Science, vol. 277, no. 5329, p. 1063-1066. [CrossRef]

THIEL, T.; MICHALEK, W.; VARSHNEY, R.K. and GRANER, A. (2003). Exploiting EST databases for the development and characterization of gene-derived SSR-markers in barley (Hordeum vulgare L.). TAG Theoretical and Applied Genetics, vol. 106, no. 3, p. 411-422. [CrossRef]

UYSAL, H.; FU, Y.B.; KURT, O.; PETERSON, G.W.; DIEDERICHSEN, A. and KUSTERS, P. (2010). Genetic diversity of cultivated flax (Linum usitatissimum L.) and its wild progenitor pale flax (Linum bienne L.) as revealed by ISSR markers. Genetic Resources and Crop Evolution, vol. 57, no. 7, p. 1109-1119. [CrossRef]

VARSHNEY, R.K.; GRANER, A. and SORRELLS, M.E. (2005). Genic microsatellite markers in plants: Features and applications. Trends in Biotechnology, vol. 23, no. 1, p. 48-55. [CrossRef]

WANG, H.Y.; WEI, Y.M.; YAN, Z.H. and ZHENG, Y.L. (2007). EST-SSR DNA polymorphism in durum wheat (Triticum aestivum L.) collections. Journal of Applied Genetics, vol. 48, no. 1, p. 37-42.

WANG, J.Y.; ZHENG, L.S.; HUANG, B.Z.; LIU, W.L. and WU, Y.T. (2010). Development, characterization and variability analysis of microsatellites from a commercial cultivar of Musa acuminate. Genetic Resources and Crop Evolution, vol. 57, no. 4, p. 553-563. [CrossRef]

WIESNEROVÁ, D. and WIESNER, I. (2004). ISSR-based clustering of cultivated flax germplasm is statistically correlated to thousand seed mass. Molecular Biotechnology, vol. 26, no. 3, p. 207-214. [CrossRef]

WINKLER, H. (1931). Linaceae, tribe I. Linoideae-eulinae. In: ENGLER, A. eds. Die nature-lichen pfanzenfamilien nebst ihren Gattungen und wichtigeren Arten, insbesondere den Nutzpflanzen. W. Engelmann, Leipzig, Germany, 1931. p. 111-120.

YONEMARU, J.; ANDO, T.; MIZUBAYASHI, T.; KASUGA, S.; MATSUMOTO, T. and YANO, M. (2009). Development of genome-wide simple sequence repeat markers using whole-genome shotgun sequences of sorghum (Sorghum bicolor (L.) moench). DNA Research, vol. 16, no. 3, p. 187-193. [CrossRef]

YU, J.K.; DAKE, T.M.; SINGH, S.; BENSCHER, D.; LI, W.; GILL, B. and SORRELLS, M.E. (2004). Development and mapping of EST-derived simple sequence repeat markers for hexaploid wheat. Genome, vol. 47, no. 5, p. 805-818. [CrossRef]

ZHANG, L.Y.; BERNARD, M.; LEROY, P.; FEUILLET, C. and SOURDILLE, P. (2005). High transferability of bread wheat EST-derived SSRs to other cereals. TAG Theoretical and Applied Genetics, vol. 111, no. 4, p. 677687. [CrossRef]

\section{How to cite this article:}

SOTO-CERDA, B.J.; URBINA SAAVEDRA, H.; NAVARRO NAVARRO, C. and MORA ORTEGA, P. (2011). Characterization of novel genic SSR markers in Linum usitatissimum (L.) and their transferability across eleven Linum species. Electronic Journal of Biotechnology, vol. 14, no. 2. http://dx.doi.org/10.2225/vol14-issue2fulltext-6 